\title{
The influence of laser heat treatment on the geometric structure of the surface and condition of the surface layer and selected properties of Waspaloy
}

\author{
Aneta Bartkowska ${ }^{1, *}$, Mateusz Kukliński ${ }^{2}$, and Piotr Kieruj ${ }^{2}$ \\ ${ }^{1}$ Poznan University of Technology, Institute of Material Science and Engineering, Jana Pawła II 24, \\ 60-965, Poznan, Poland \\ ${ }^{2}$ Poznan University of Technology, Institute of Mechanical Technology, Piotrowo 3, 60-965, Poznan, \\ Poland
}

\begin{abstract}
In the aviation industry the nickel-based superalloys such as Waspaloy are very often used. Conventional machining of this alloys is difficult and expensive. Therefore a Waspaloy requires the new techniques for machining like e.g. Laser Assisted Machining (LAM). New development directions of mechanical engineering are focusing on this type of hybrid machining, where materials are heated and cut in the single process. LAM enables increasing the material machinability through the increase of its temperature in cutting zone. It is assumed that additional increased temperature in the contact zone between surface of material and cutting tool causes the increase of machinability. This paper presents the results of laser heat treatment process on Waspaloy material. The influence of laser heat treatment parameters on the surface condition and selected properties of Waspaloy were analyzed. Laser heat treatment was carried out using diode laser with nominal power equaled to $3.0 \mathrm{~kW}$. The laser beam power density and its scanning laser beam velocity were analyzed. In the first step the single laser tracks were prepared and analyzed. In the second step the multiple laser tracks were prepared. The special attention was directed on change in microstructure. It was found that the laser heat treatment have significant influence on microstructure. The dendritic microstructure of Waspaloy which is characterized by a lower microhardness, causes better machinability of this material.
\end{abstract}

\section{Introduction}

One of the new techniques which improves the machinability of material is a Laser Assisted Machining (LAM). This technique focuses on increasing machinability of material through the increase of its temperature in cutting zone, as a result of laser beam effect [1-7]. However, before beginning such treatment, it is necessary to know what happens to the material only after the heating [8]. In many papers are analyzed problems of laser heating

\footnotetext{
*Corresponding author: aneta.bartkowska@put.poznan.pl
} 
of material (iron and non-ferrous alloy) and occurring changes in it [9-12]. In the last time a lot of attention is directed to non-ferrous alloys such as nickel alloy. Also, the emphasis is put on the machinability improvement of difficult-to-cut materials [13-14]. The group of difficult-to-cut materials undoubtedly include nickel alloys such as Waspaloy [9-10] or alloys reinforced with $\mathrm{SiC}[1,3-5], \mathrm{WC}[7,15-16]$ particles. There is a tendency to create products of higher quality in a shorter time and at a lower cost. To achieve some of the stated objectives, there is a need to use hard and resistant materials which usually have low machinability.

Therefore for the aim of this study was to determine the appropriate laser heat treatment parameters on dimensions of laser tracks and their microstructure. This step is a very important during the Laser Assisted Machining of material.

\section{Research method}

Studies were carried out on the specimens made on nickel-based superalloys such as Waspaloy. The samples of Waspaloy alloy with the following dimensions $20 \mathrm{~mm}$ x $30 \mathrm{~mm}$ $\mathrm{x} 12 \mathrm{~mm}$ were subjected to laser heat treatment. Chemical composition of this material is shown in Table 1.

Table 1. Chemical composition of Waspaloy [\%wt.]

\begin{tabular}{|c|c|c|c|c|c|c|c|c|}
\hline $\mathrm{C}$ & $\mathrm{Cr}$ & $\mathrm{Co}$ & $\mathrm{Mo}$ & $\mathrm{Ti}$ & $\mathrm{Al}$ & $\mathrm{B}$ & $\mathrm{Fe}$ & $\mathrm{Ni}$ \\
\hline 0.06 & 19.5 & 13.5 & 4.25 & 3.1 & 1.4 & 0.007 & 1.0 & balance \\
\hline
\end{tabular}

The influence of laser heat treatment parameters on the surface condition, dimensions of laser tracks, microstructure and microhardness of Waspaloy were analyzed. In the first step the single laser tracks were prepared and analyzed. Then, in the second step the multiple laser tracks were prepared. The aim of this step was to obtain a uniform remelted area dependent on distance of laser tracks between each other. Laser heat treatment by using the TRUDIODE 3006 diode laser with a nominal power of $3 \mathrm{~kW}$ was conducted. The diode laser was integrated with the robot arm KUKA. The parameters of the laser heat treatment are presented in tables 1 and 2. LHT parameters for the single laser tracks are presented in Table 1.

Table 2. The parameters LHT for the single laser tracks

\begin{tabular}{|c|c|c|}
\hline $\begin{array}{c}\mathrm{P} \\
{[\mathrm{W}]}\end{array}$ & $\begin{array}{c}\mathrm{q} \\
{\left[\mathrm{kW} / \mathrm{cm}^{2}\right]}\end{array}$ & $\begin{array}{c}\mathrm{v} \\
{[\mathrm{m} / \mathrm{min}]}\end{array}$ \\
\hline 800 & 102 & 5 \\
\hline 1400 & 178 & 5 \\
\hline 2000 & 255 & 5 \\
\hline 2600 & 331 & 5 \\
\hline 1400 & 178 & 25 \\
\hline 1400 & 178 & 50 \\
\hline 1400 & 178 & 75 \\
\hline 1400 & 178 & 100 \\
\hline
\end{tabular}

LHT parameters for the multiple laser tracks are presented in Table 2. Table 1 and 2 present: laser beam power $\mathrm{P}[\mathrm{W}]$, laser beam power density $\mathrm{q}\left[\mathrm{kW} / \mathrm{cm}^{2}\right]$, scanning laser beam velocity $\mathrm{v}[\mathrm{m} / \mathrm{min}]$ and laser tracks overlap $\mathrm{O}[\%]$, which depends on distance between the laser tracks $\mathrm{f}[\mathrm{mm}]$.

Overlap of laser tracks is defined by the formula: 


$$
O=\left[\left(\mathrm{b}_{1}-\mathrm{f}\right) / \mathrm{b}_{1}\right] \cdot 100 \%
$$

where:

$\mathrm{b}_{1}$ - diameter of laser beam [mm]

$\mathrm{f}$ - distance between the laser tracks [mm].

In this study the diameter of laser beam was of $1 \mathrm{~mm}$.

Table 3. The parameters LHT for the multiple laser tracks

\begin{tabular}{|c|c|c|c|c|}
\hline $\begin{array}{c}\mathrm{P} \\
{[\mathrm{W}]}\end{array}$ & $\begin{array}{c}\mathrm{q} \\
{\left[\mathrm{kW} / \mathrm{cm}^{2}\right]}\end{array}$ & $\begin{array}{c}\mathrm{v} \\
{[\mathrm{m} / \mathrm{min}]}\end{array}$ & $\begin{array}{c}\mathrm{f} \\
{[\mathrm{mm}]}\end{array}$ & $\begin{array}{c}\mathrm{O} \\
{[\%]}\end{array}$ \\
\hline \multirow{3}{*}{1400} & & & 1.00 & 0 \\
\cline { 4 - 5 } & \multirow{3}{*}{178} & \multirow{3}{*}{75.0} & 0.50 & 50 \\
\cline { 4 - 5 } & & & 0.25 & 75 \\
\cline { 4 - 5 } & & & 0.125 & 87.5 \\
\hline
\end{tabular}

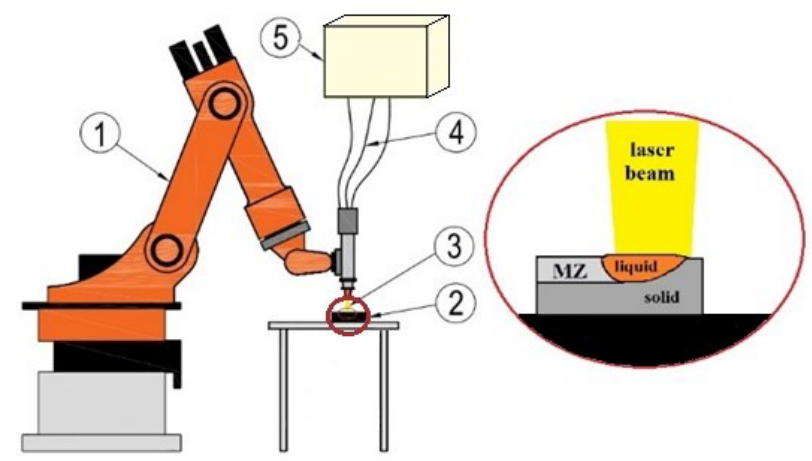

Fig. 1. Scheme of laser heat treatment process: 1) KUKA robot, 2) specimen, 3) laser beam, 4) optic fibers, 5) optic resonator

The view of the test stand of diode laser with the KUKA robot and diagram of remelting of surface layer by using the laser beam are shown in Figure 1. The dimensions of laser tracks were measured on the cross-sections of laser tracks, using Axio Vision software. Width (W) and depth (d) were measured for single laser tracks, while for multiple laser tracks the effective layer thickness $\left(\mathrm{t}_{\mathrm{ef}}\right)$ was measured. The designation of measurement of dimensions on laser tracks cross-sections sample are shown in Figure 2.
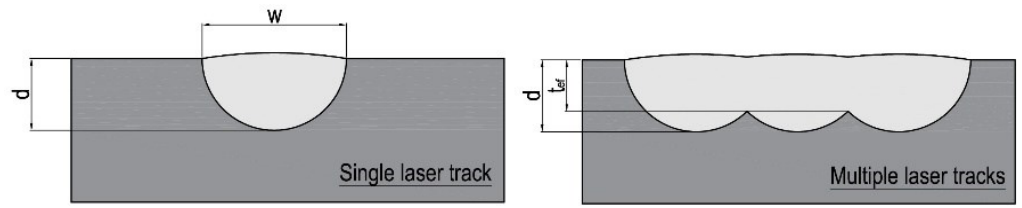

Fig. 2. Laser tracks dimensions locations: $\mathrm{W}$ - width of laser track, $\mathrm{d}$ - depth of laser track, tef effective layer thickness

Macroscopic photos were made using Zeiss Stereo Discovery V20 camera. 3D topography images were made by profile meter Hommel tester H8000.

Microstructure observations were carried out on cross-sections of specimens ground with abrasive papers of grit ranged from 120 to 2000 and subsequently polished using 
aluminum oxide suspension after etching in Marble's reagent. For this purpose the Carl Zeiss Metaval microscope equipped with Moticam 2300 3.0 MP Live camera was applied. To determine microhardness profiles, Zwick 3212B Vickers hardness tester was used. Indentation load of $100 \mathrm{G}$ and loading time 15 seconds were applied in these studies.

\section{Results and discussion}

Figure 3 presents the macroscopic images of Waspaloy surface after laser heat treatment for single laser tracks. Figures $3 \mathrm{a}$ to $3 \mathrm{~d}$ presents the influence of laser beam power density at the constant scanning laser beam velocity on surface of Waspaloy. The movements direction of liquid material is clearly visible in Figure $3 \mathrm{a}$.

With increasing the laser beam power density in the central area of laser tracks the solidified drops of metal appear on the sample surface. Those drops are clearly visible in Figures $3 \mathrm{c}$ and $3 \mathrm{~d}$. Figure $3 \mathrm{e}-3 \mathrm{~h}$ presents the macroscopic images when the laser beam power density is constant, and scanning laser beam velocity is variable. Here is visible similar dependency, which shows that with increasing of scanning laser beam velocity the dimensions of laser tracks are decreased. Increasing the scanning laser beam velocity affects the rapid cooling of material which can be also observed as solidified drops of metal on Waspaloy sample's surface (Fig. 3g and Fig. 3h).

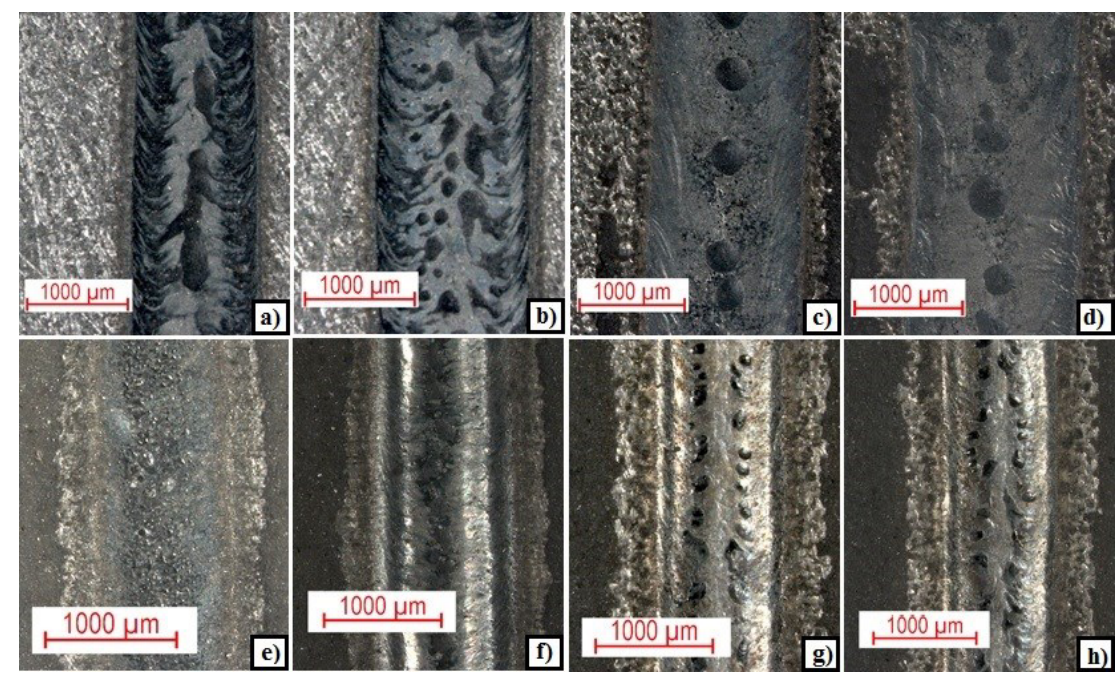

Fig. 3. Macroscopic image of Waspaloy surface after laser heat treatment - single laser tracks: a) LHT: $\mathrm{q}=102 \mathrm{~kW} / \mathrm{cm}^{2}, \mathrm{v}=5 \mathrm{~m} / \mathrm{min}$; b) LHT: $\mathrm{q}=178 \mathrm{~kW} / \mathrm{cm}^{2}, \mathrm{v}=5 \mathrm{~m} / \mathrm{min}$; c) LHT: $\mathrm{q}=255 \mathrm{~kW} / \mathrm{cm}^{2}, \mathrm{v}=5 \mathrm{~m} / \mathrm{min}$; d)LHT: $\mathrm{q}=331 \mathrm{~kW} / \mathrm{cm}^{2}, \mathrm{v}=5 \mathrm{~m} / \mathrm{min}$; e) LHT: $\mathrm{q}=178 \mathrm{~kW} / \mathrm{cm}^{2}$, $\mathrm{v}=25 \mathrm{~m} / \mathrm{min}$; f) LHT: $\mathrm{q}=178 \mathrm{~kW} / \mathrm{cm}^{2}, \mathrm{v}=50 \mathrm{~m} / \mathrm{min}$; g) LHT: $\mathrm{q}=178 \mathrm{~kW} / \mathrm{cm}^{2}, \mathrm{v}=75 \mathrm{~m} / \mathrm{min}$; h) LHT: $\mathrm{q}=178 \mathrm{~kW} / \mathrm{cm}^{2}, \mathrm{v}=100 \mathrm{~m} / \mathrm{min}$.

Figure 4 presents the macroscopic images of surface Waspaloy after laser heat treatment for multiple laser tracks. Figures $4 \mathrm{a}-4 \mathrm{~d}$ present surface of laser tracks where is visible the entire width of laser track, whereas the Figures $4 \mathrm{e}-4 \mathrm{~h}$ present the magnified areas of Figures $4 a-4 d$. It can be seen the influence of distance between the laser tracks on surface of material. In Figure $4 \mathrm{a}$ the distance between the laser tracks was of $1 \mathrm{~mm}$. With decreasing distance between adjacent laser tracks, the overlap of laser tracks is increasing (Figs. 4b-d). Figure 5 presents 3D images of roughness of the Waspaloy surface after laser heat treatment for multiple laser tracks. With increasing the overlap of laser tracks, the roughness of the Waspaloy surface after laser heat treatment decreases. The results of $S_{a}$ 
and $S_{z}$ roughness parameters are presented in Table 4 . The $S_{a}$ parameter is an average roughness deviation and $S_{z}$ parameter is a ten-point surface irregularities height. It was found that surface roughness decreases when laser tracks are closer to each other.

Table 4. The roughness parameters after LHT for the multiple laser tracks

\begin{tabular}{|c|c|c|c|c|c|c|}
\hline $\begin{array}{c}\mathrm{P} \\
{[\mathrm{W}]}\end{array}$ & $\begin{array}{c}\mathrm{q} \\
{\left[\mathrm{kW} / \mathrm{cm}^{2}\right]}\end{array}$ & $\begin{array}{c}\mathrm{v} \\
{[\mathrm{m} / \mathrm{min}]}\end{array}$ & $\begin{array}{c}\mathrm{f} \\
{[\mathrm{mm}]}\end{array}$ & $\begin{array}{c}\mathrm{O} \\
{[\%]}\end{array}$ & $\begin{array}{c}\mathrm{S}_{\mathrm{a}} \\
{[\mu \mathrm{m}]}\end{array}$ & $\begin{array}{c}\mathrm{S}_{\mathrm{z}} \\
{[\mu \mathrm{m}]}\end{array}$ \\
\hline \multirow{3}{*}{1400} & & & 1.00 & 0 & 10.0 & 86.6 \\
\cline { 4 - 7 } & \multirow{3}{*}{178} & \multirow{2}{*}{75.0} & 0.50 & 50 & 4.6 & 41.8 \\
\cline { 4 - 7 } & & & 0.25 & 75 & 5.6 & 50.1 \\
\cline { 3 - 7 } & & & 0.125 & 87.5 & 1.9 & 20.2 \\
\hline
\end{tabular}

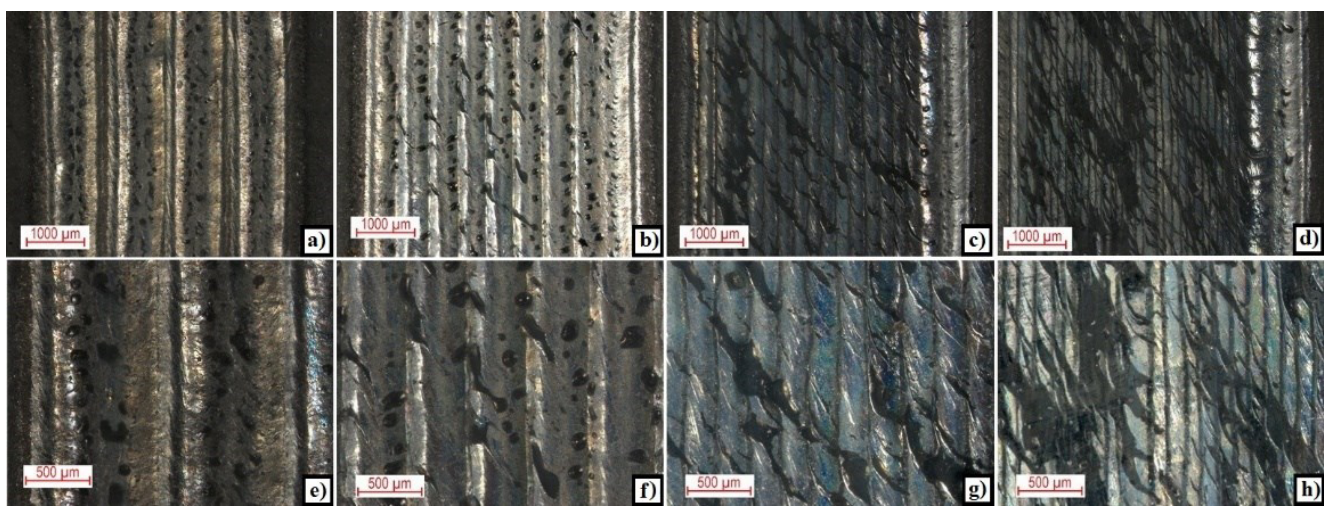

Fig. 4. Macroscopic image of Waspaloy surface after laser heat treatment - multiple laser tracks: a, e - LHT: $q=178 \mathrm{~kW} / \mathrm{cm}^{2}, \mathrm{v}=75 \mathrm{~m} / \mathrm{min}, \mathrm{O}=0 ; \mathrm{b}, \mathrm{f}-$ LHT: $\mathrm{q}=178 \mathrm{~kW} / \mathrm{cm}^{2}, \mathrm{v}=75 \mathrm{~m} / \mathrm{min}$, $\mathrm{O}=50 ; \mathrm{c}, \mathrm{g}$ - LHT: $\mathrm{q}=178 \mathrm{~kW} / \mathrm{cm}^{2}, \mathrm{v}=75 \mathrm{~m} / \mathrm{min}, \mathrm{O}=75 ; \mathrm{d}, \mathrm{h}-$ LHT: $\mathrm{q}=178 \mathrm{~kW} / \mathrm{cm}^{2}$, $\mathrm{v}=75 \mathrm{~m} / \mathrm{min}, \mathrm{O}=87.5$
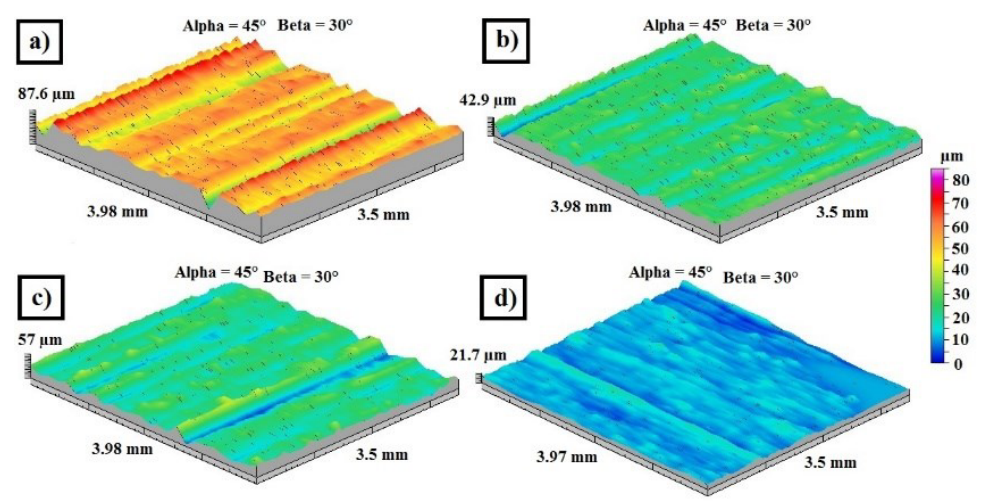

Fig. 5. 3D images of roughness of the Waspaloy surface after laser heat treatment:

a) LHT: $\mathrm{q}=178 \mathrm{~kW} / \mathrm{cm}^{2}, \mathrm{v}=75 \mathrm{~m} / \mathrm{min}, \mathrm{O}=0$; b) LHT: $\mathrm{q}=178 \mathrm{~kW} / \mathrm{cm}^{2}, \mathrm{v}=75 \mathrm{~m} / \mathrm{min}, \mathrm{O}=50$;

c) LHT: $\mathrm{q}=178 \mathrm{~kW} / \mathrm{cm}^{2}, \mathrm{v}=75 \mathrm{~m} / \mathrm{min}, \mathrm{O}=75$; d) LHT: $\mathrm{q}=178 \mathrm{~kW} / \mathrm{cm}^{2}, \mathrm{v}=75 \mathrm{~m} / \mathrm{min}, \mathrm{O}=87.5$

Figures $6 \mathrm{a}-6 \mathrm{c}$ show a single laser tracks obtained at a constant scanning laser beam velocity $\mathrm{v}=5.1 \mathrm{~m} / \mathrm{min}$ and a variable laser beam power density. It can be seen that the with the increasing the laser beam power density the dimensions of the laser tracks are increasing. 
In the plane perpendicular to the direction of melting, a dendritic and column crystals oriented in the direction of heat dissipation can be observed. In the remelted zone, where it followed a change of direction of heat dissipation, the crystals grow almost parallel to the direction of heat, so the microstructure is equated. When is a sufficiently large supercooling, the character of crystals changes, and second order branches characteristic to a dendritic growth appear. This dependency is clearly visible in Figures $6 \mathrm{~b}$ and $6 \mathrm{c}$. The columnar and dendritic crystals in the microstructure are bigger when the higher laser beam power density is used.

Figures $6 \mathrm{~d}-6 \mathrm{f}$ show a single laser tracks produced at constant laser beam power density $\mathrm{q}=178 \mathrm{~kW} / \mathrm{cm}^{2}$ and variable scanning laser beam velocity. In this study the speed of laser heating corresponds to the most commonly used cutting speeds of applied materials. There is a certain dependence that with increasing scanning laser beam velocity, the dimensions of laser tracks are decreasing.

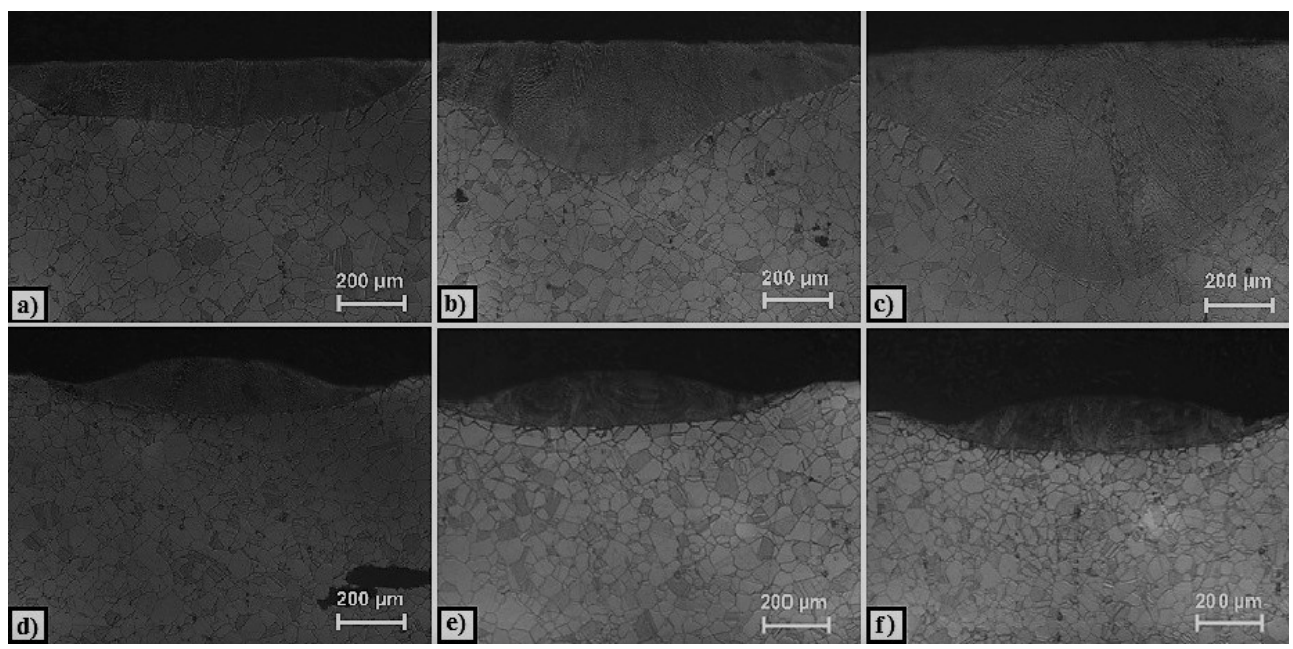

Fig. 6. Macrostructure of Waspaloy surface after laser heat treatment - single laser tracks: a) LHT: $\mathrm{q}=102 \mathrm{~kW} / \mathrm{cm}^{2}, \mathrm{v}=5 \mathrm{~m} / \mathrm{min}$; b) LHT: $\left.\mathrm{q}=178 \mathrm{~kW} / \mathrm{cm}^{2}, \mathrm{v}=5 \mathrm{~m} / \mathrm{min} ; \mathrm{c}\right)$ LHT: $\mathrm{q}=255 \mathrm{~kW} / \mathrm{cm}^{2}$, $\mathrm{v}=5 \mathrm{~m} / \mathrm{min}$; d) LHT: $\mathrm{q}=178 \mathrm{~kW} / \mathrm{cm}^{2}, \mathrm{v}=50 \mathrm{~m} / \mathrm{min}$; e) LHT: $\mathrm{q}=178 \mathrm{~kW} / \mathrm{cm}^{2}, \mathrm{v}=75 \mathrm{~m} / \mathrm{min}$; f) LHT: $q=178 \mathrm{~kW} / \mathrm{cm}^{2}, \mathrm{v}=100 \mathrm{~m} / \mathrm{min}$

Figure 7 presents the microstructure of multiple laser tracks. Figures $7 \mathrm{e}-7 \mathrm{~h}$ presents the magnified area from Figures $7 \mathrm{a}-7 \mathrm{~d}$. In the microstructure of the laser track cracks can be observed which are likely related to the high scanning speed of the laser beam, as well as heating and cooling of the material using a small distances between adjacent tracks. Probably the cracks may arise during the contraction of material after rapid cooling and solidification to the ambient temperature, and then re-heating it.

For the scanning laser beam velocity $\mathrm{v}=75.0 \mathrm{~m} / \mathrm{min}$ and the distance between the laser tracks $\mathrm{f}=0.25 \mathrm{~mm}$ (Fig. 7c) and $\mathrm{f}=0.125 \mathrm{~mm}$ (Fig. 7d), the numerous cracks were observed in the microstructure of surface layer. Selection of parameters for the laser treatment is important with regard to obtaining a continuous surface layer with uniform thickness. It can be seen that the smaller the distance $f$, the thicker effective layer.

When the value of the parameter $\mathrm{f}$ is higher (distance between laser track is are large) the depth in the axis and in the borders of laser tracks are various. A lower value of the parameter $\mathrm{f}$ affects the total fulfillment of the work surface. In this case the best parameters can be considered as: $\mathrm{q}=178 \mathrm{~kW} / \mathrm{cm}^{2}, \mathrm{v}=75 \mathrm{~m} / \mathrm{min}, \mathrm{f}=0.5 \mathrm{~mm}$. Too large distance between laser tracks is not conducive to completing the entire surface workpiece, which can affect the worse machinability in areas where the material was not heated. On the other 
hand, too small distance between laser tracks can cause cracks in the material after laser heating, which may result in propagation of cracks into the based material.

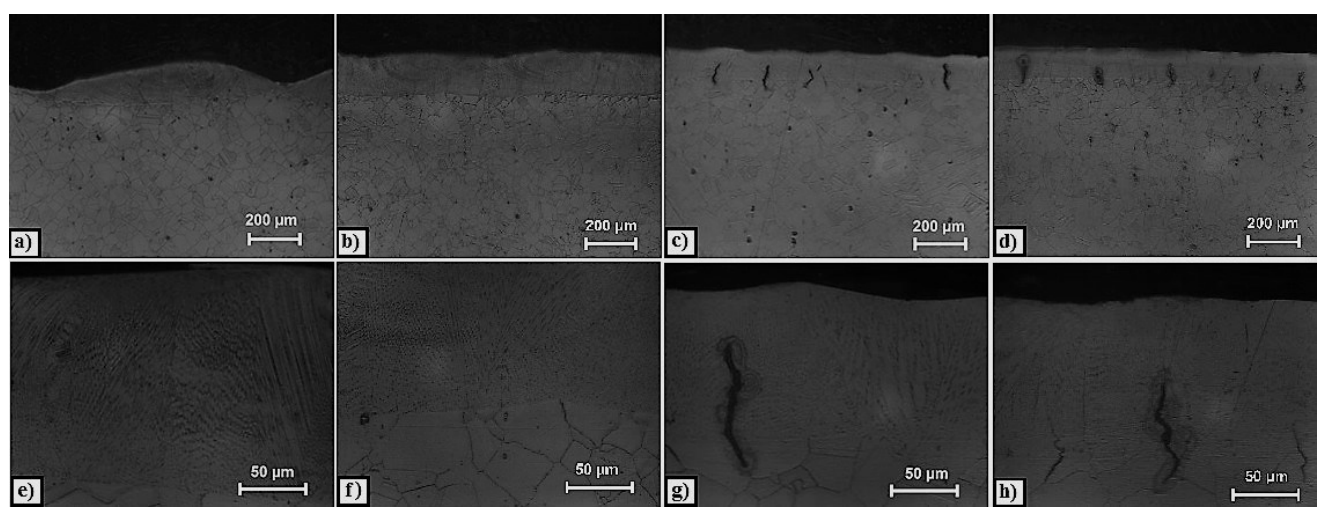

Fig. 7. Macrostructure of Waspaloy surface after laser heat treatment - multiple laser tracks: a, e LHT: $\mathrm{q}=178 \mathrm{~kW} / \mathrm{cm}^{2}, \mathrm{v}=75 \mathrm{~m} / \mathrm{min}, \mathrm{O}=0$; $\mathrm{b}, \mathrm{f}-$ LHT: $\mathrm{q}=178 \mathrm{~kW} / \mathrm{cm}^{2}, \mathrm{v}=75 \mathrm{~m} / \mathrm{min}, \mathrm{O}=50 ; \mathrm{c}, \mathrm{g}$ - LHT: $\mathrm{q}=178 \mathrm{~kW} / \mathrm{cm}^{2}, \mathrm{v}=75 \mathrm{~m} / \mathrm{min}, \mathrm{O}=75$; d, h - LHT: $\mathrm{q}=178 \mathrm{~kW} / \mathrm{cm}^{2}, \mathrm{v}=75 \mathrm{~m} / \mathrm{min}, \mathrm{O}=87.5$

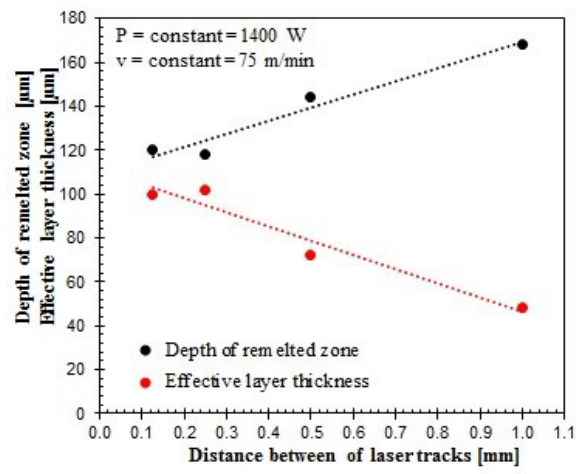

Fig. 8. The influence of distance between of laser tracks on a depth of remelted zone and effective thickness; $\mathrm{P}=$ constant $=1400 \mathrm{~W}, \mathrm{q}=$ constant $=178 \mathrm{~kW} / \mathrm{cm}^{2}$ and $v=$ constant $=75 \mathrm{~m} / \mathrm{min}$

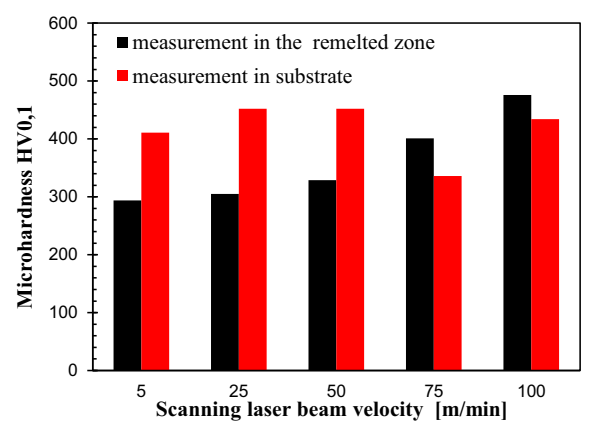

Fig. 9. The influence of scanning laser beam velocity on microhardness in remelted zone and the substrate for a constant of laser beam power density $\mathrm{q}=178 \mathrm{~kW} / \mathrm{cm}^{2}$

Figure 8 presents the influence of distance between the laser tracks on a depth of remelted zone and effective thickness for a $\mathrm{q}=$ constant $=178 \mathrm{~kW} / \mathrm{cm}^{2}$ and $\mathrm{v}=$ constant $=$ $75 \mathrm{~m} / \mathrm{min}$. Reducing the distance between laser tracks influences the increase of the effective thickness of layer. For the largest completing the working surface, the depth of 
remelted zone and the effective thickness layer have a similar value. However, such high scanning laser beam velocity and high laser beam power density is not recommended, because in the surface layer the numerous cracks can appear. Figure 9 shows the influence of scanning laser beam velocity on the microhardness of the layer and the substrate at a constant laser beam power density $q=178 \mathrm{~kW} / \mathrm{cm}^{2}$. It can be seen that with the increase of the scanning laser beam velocity, the microhardness decreases. Its value was equaled to about $500 \mathrm{HV} 0,1$ in a substrate, and about $300 \mathrm{HV} 0,1$ in surface layer. This phenomenon is advantageous because it allows easier machining of the material.

\section{Conclusions}

Based on the results of laser heating of Waspaloy it was found that laser heat treatment parameters have a significant impact on the microstructure and the microhardness of Waspaloy. By adjusting the laser heat treatment parameters such as the beam power density, scanning laser beam velocity and the distance between the laser tracks, the appropriate thickness of the melted zone can be obtained. As the most advantageous parameters of laser heating, the $\mathrm{q}=178 \mathrm{~kW} / \mathrm{cm}^{2}, \mathrm{v}=75 \mathrm{~m} / \mathrm{min}, \mathrm{f}=0.5 \mathrm{~mm}$ can be selected. These parameters allow the reduction of hardness in cutting zone, which can cause the tool life improvement. Proposed parameters of laser heating for the Laser Assisted Machining (LAM) method are most preferred because they provide a continuous layer, free of cracks.

Acknowledgement: The presented research results, executed under the domestic project PBS of No 244445 , were funded with grants for education allocated by the National Centre for Research and Development

\section{References}

1. M. Kawalec, D. Przestacki, K. Bartkowiak, M. Jankowiak. ICALEO 27th International Congress on Applications of Lasers and Electro-Optics, Congress Proceedings, 895-900D (2008)

2. H. Ding, Y. C. Shin. Int J Adv Manuf Tech, 64, 475-486 (2013)

3. D. Przestacki, M. Jankowiak. Journal of Physics: Conference Series, 483, 012019, 1-7, (2014)

4. D. Przestacki. Procedia CIRP 14, 229-233 (2014)

5. D. Przestacki, P. Szymanski, S. Wojciechowski. Composites: Part A, 91, 370-379 (2016)

6. S. A. Tadavani, R. S. Razavin, R. Vafaei. OPT Laser Technol, 87, $72-78$ (2017)

7. D. Przestacki, T. Chwalczuk, S. Wojciechowski. Int J Adv Manuf Technol, 1-12 (2017)

8. Steen M. W., Mazumder J. Laser Material Processing, (Springer, 2010)

9. K. A. Mumtaz, P. Erasenthiran, N. Hopkinson. J Mater Process Tech, 195, $77-87$ (2008)

10. R. S. Razavi. Opt Laser Technol, 82, 113-120 (2016)

11. Y.-J. Liang, J. Li, A. Li, X.-T. Pang, H.-M. Wang. Scripta Mater, 127, 58-62 (2017)

12. Y. Li, L. Zhou, W. He, G. He, X. Wang, X. Nie, B. Wang, S. Luo, Y. Li, Sci. Technol. Adv. Mater. 14, 055010, 1-9 (2013)

13. S. Wojciechowski et al. Precis Eng, 46, 158-165 (2016)

14. S. Wojciechowski et al. Int J Mech Sci, 119, 360-369 (2016)

15. D. Bartkowski, G. Kinal. Int J Refract Met H, 58, 157-164 (2015)

16. D. Bartkowski, A. Młynarczak, A. Piasecki, B. Dudziak, M. Gościański, A. Bartkowska, Opt Laser Technol, 68, 191-201 (2015) 